\title{
Geometrical Visualization
} \section{and Students' Cognitive Style}

\author{
Noor Fajriah \\ Mathematics Education \\ Lambung Mangkurat University, \\ Banjarmasin \\ Surabaya State University, \\ Surabaya, Indonesia \\ n.fajiriah@ulm.ac.id and \\ noorfajriah@mhs.unesa.ac.id
}

\author{
Akbar Sutawidjaja \\ Mathematics Education \\ Malang State University \\ Malang, Indonesia \\ akbarsutawidjaja@gmail.com
}

\author{
Tatag Yuli Eko Siswono \\ Mathematics Education \\ Surabaya State University \\ Surabaya, Indonesia \\ tatagsiswono@unesa.ac.id
}

\begin{abstract}
Students' naturally have different characteristic especially cognitive style. When they solve geometrical problems, their visualization could be varied depending on his understanding and viewpoint. This research aim is to describe students visualization type in solving geometrical problems regarding dependent and independent students. The research participant is one independent students' and one dependent students' in 9th grade. Collecting data was used by semi-structured interview and analyzed by data reduction, displaying data, and interpretationverification. Some results pointed out that independent students' visualization types were perceptual, sequential, discursive, and operative apprehension. It is better than dependent students' visualization types have no perceptual apprehension.
\end{abstract}

Keywords-visualization, independent, field dependent

apprehension, field

\section{INTRODUCTION}

Visualization and geometry are inter-correlated and important for students. Visualization is one of the useful skill for students in solving the geometry problem [6] while geometry is part of mathematics that can develop the visualization skill. As stated by Jones [14] "geometry is a wonderful area of mathematics to teach. It is full of interesting problems and surprising theorems. The study of geometry contributes to helping students develop the skills of visualization, critical thinking, intuition, perspective, problem-solving, conjecturing, deductive reasoning, logical argument and proof" (p. 122).

Visualization is required due to the object of geometry or mathematics will be difficult to be understood if delivered using symbol and abstract for the students who not reach the formal thinking stage. Commonly the elementary school students and junior high school students do not reach yet that stage. To settle this problem then the mathematics teacher requires object visualization of mathematics or abstract geometry. In accordance with the statement of [24] that visualization is very useful to understand such problem, simplify the problems, observe the problem with the related connection, and change the problems become the mathematical objects. It is also supported by the research of [17] that about $70 \%$ teachers convey that by the visualization in mathematics particularly in geometry, it makes students easy to find the answer because it is expected that the students get additional information in solving the problems from the illustration.

In fact, visualization is one of the materials that considered as difficult material by the student's 7 th grade of Cyprus [16]. It is supported by [6] who states that the geometry learning is more complex and often less successful than the numeric operational learning or basic algebra. [7] says that visualization needs to be learned and practiced because it is not easy. Geometrical object or Cartesian chart not directly provided as the iconic representation and need time so that the students can construct their understanding.

[12] says that mathematical visualization is a concrete illustration of the abstract mathematical object. Furthermore, [25] tell that visualization is the interpretation skill, pictures utilization, and reflection, the diagram on the brain, on the paper or using technology for the purpose of depicting and communicating the information, thinking and developing the ideas that previously unknown. [22] say that visualization is divided into four types namely perceptual apprehension, sequential apprehension, discursive apprehension and operative apprehension. Perceptual apprehension is the initial activity in solving the problem by recalling the condition of the geometrical object, sequential apprehension is the activity of constructing the geometrical object so in accordance with the rules. This activity is expected to be related to the mathematical characteristics of geometrical objects. Discursive apprehension is the activity of identifying the geometrical objects with its characteristics. Operative apprehension is the activity that can be divided or differentiate the new object from the initial object.

The visualization type of each student in problemsolving possibly is different because of each characteristics difference. One of the characteristics that differentiate each student is a cognitive style. The cognitive style is the basic that differentiate people when they have interaction with various situations, the important approach to understand, learn or think [20]. The cognitive style used in the current research is the cognitive style of field dependent and field independent. [19] says that the individual with field dependent accepts something more global and have difficulties in separating from the surrounding 
circumstances; they tend to consider they themselves as the part of the group. This individual in social orientation tends to be more perceptive and sensitive. In vice versa, the individual with field independent tends to state a loose picture of the background of it, and able to differentiate the objects from the surrounding context easier. They consider the surrounding condition more analytic.

There are many studies about cognitive style with various results. [13] say that there is a significant difference in solving the geometrical problem based on the cognitive style. [8] say that there is a significant difference between Junior High School students' ability in solving the mathematics problem based on the cognitive style. Even [1] also state that there is a significant relationship between the cognitive style with the academic achievement. In addition, [9] also show that there is a significant relationship between the cognitive style with the ability in solving the geometry problems. However, the different statement delivered by [13] that there is no difference in the creativity in solving the geometrical problem based on cognitive style. [21] also tell the same thing that there is no difference in elementary students' ability in solving the mathematics based on cognitive style.

The problem-solving ability in mathematics is important because it is one of the competencies should be achieved by students. If the problem-solving ability is the heart of mathematics, then visualization is the core of problem-solving. [18] says that there 4 (four) main steps in solving the mathematics problem those are: (1) understanding problem, (2) think/arrange the plan; (3) conducting the plan, (4) recheck the result. Understanding problem is the activity of identifying the thing questioned to be solved and the facts given. Arrange the plan: an activity for looking the relating between the unknown data. This step is also related to the strategy used in solving the problem. [4] give several strategies to solve the problem of geometry type for students in 13-14 years i.e.: making a drawing, using known information, simplifying the problem, brainstorming and intelligent guessing and testing strategy. Conducting the solving plan is the step where the students use their arithmetic skill, algebra as well as implement the strategy to solve the problem. Recheck the result is to ensure that there is no computation and check the rational answer. If the answer meaningful, using size unit and the question that actually have been answered.

This research aim is to describe students visualization type in solving geometrical problems regarding dependent and independent students. for every step of Polya's problem-solving.

\section{METHODS}

The current research is explorative research with a qualitative approach. The participant is chosen from 9th grade of SMPN 14 Banjarmasin who has a cognitive style of field dependent-independent and the similar geometry ability. The students were classified based on the result of GEFT test where the score is $0-6$ of dependent and 13-18 of independent. According to the result of the geometry test than the students can be classified into three level ability: low, medium and high. The research participant is one independent students' and one dependent s students' in the medium group namely S1 and S2. The material of geometry problem as the supporting instrument is the triangles congruence [10]. Collecting data was used by semi- structured interview and analyzed by data reduction, displaying data, and interpretation-verification.

Students' visualization type will be analyzed using the statement of [22] which is summarized in the following table 1 .

TABLE I. Characteristics of Geometrical Visualization in Problems-Solving

\begin{tabular}{|c|c|c|}
\hline Visualization & Description & Characteristics \\
\hline $\begin{array}{l}\text { Perceptual } \\
\text { Apprehension }\end{array}$ & $\begin{array}{l}\text { The initial } \\
\text { activity in } \\
\text { solving the } \\
\text { problem by } \\
\text { recalling the } \\
\text { condition of } \\
\text { the geometrical } \\
\text { object. }\end{array}$ & $\begin{array}{l}\text { Considering that } \\
\text { the geometrical } \\
\text { object is based } \\
\text { on the problem } \\
\text { information. }\end{array}$ \\
\hline $\begin{array}{l}\text { Sequential } \\
\text { Apprehension }\end{array}$ & $\begin{array}{l}\text { The activity of } \\
\text { constructing } \\
\text { the geometrical } \\
\text { object so in } \\
\text { accordance } \\
\text { with the rules. } \\
\text { This activity is } \\
\text { expected to be } \\
\text { related to the } \\
\text { mathematical } \\
\text { characteristics } \\
\text { of geometrical } \\
\text { objects. }\end{array}$ & $\begin{array}{l}\text { Construct the } \\
\text { geometrical } \\
\text { object and } \\
\text { adjusted to the } \\
\text { problem } \\
\text { information. }\end{array}$ \\
\hline $\begin{array}{l}\text { Discursive } \\
\text { Apprehension }\end{array}$ & $\begin{array}{l}\text { The activity of } \\
\text { identifying the } \\
\text { geometrical } \\
\text { objects with its } \\
\text { characteristics. }\end{array}$ & $\begin{array}{l}\text { Identify the } \\
\text { rules of } \\
\text { geometry used. }\end{array}$ \\
\hline $\begin{array}{l}\text { Operative } \\
\text { Apprehension }\end{array}$ & $\begin{array}{l}\text { The activity } \\
\text { that can be } \\
\text { divided or } \\
\text { differentiate } \\
\text { the new object } \\
\text { from the initial } \\
\text { object. }\end{array}$ & $\begin{array}{l}\text { Differentiate the } \\
\text { congruence } \\
\text { geometrical } \\
\text { object. }\end{array}$ \\
\hline
\end{tabular}

\section{RESEARCH RESULT}

\section{A. A. Visualization of Subject S1}

The subject understands the problem by reading it quietly then draws the triangle. The information received by the sensor memory is transferred to short-term memory adjusted to the initial knowledge of the subject to be interpreted as perception. The perception process is done by the subject from the top to the bottom where he develops the calculations of two-dimension figure related to the perception based on the problem. So the subject draws the isosceles triangle as the geometrical object in accordance with the information. The activity of perceptual apprehension is conducted to know the angle position questioned and easier to understand the means of the problem given. The symbol language used by the subject write on the geometrical figure is the name of each angle based on the information, the number that represents the known angle size.

The problem-solving strategy used by the subject is making a drawing and using known information. In the step 
of arranging the plan of problem-solving the subject construct the geometrical object using tools to construct the straight line but not used as the measurement tool. The activity of sequential apprehension conducted by the subject in constructing the geometrical object is orderly and in accordance with geometrical rules. The symbol used by the subject is writing on the picture of the point name, same length $(\mathbb{I})$, and the number that represent the known measure of the angle.

The subject in the step of solving problem is able to differentiate between the geometrical object and the rules quickly and precisely which means the subject not get any difficulties in conducting operative apprehension. The subject is able to analyze most of the rules related to the geometrical object and the reason commonly means the subject is able to conduct the discursive apprehension generally. The symbol language used is the number that represents angle size, angle, and sum and subtraction operation. In the recheck step, the subject conducts an activity of discursive apprehension using two rules. The following is the geometrical object constructed by the subject.

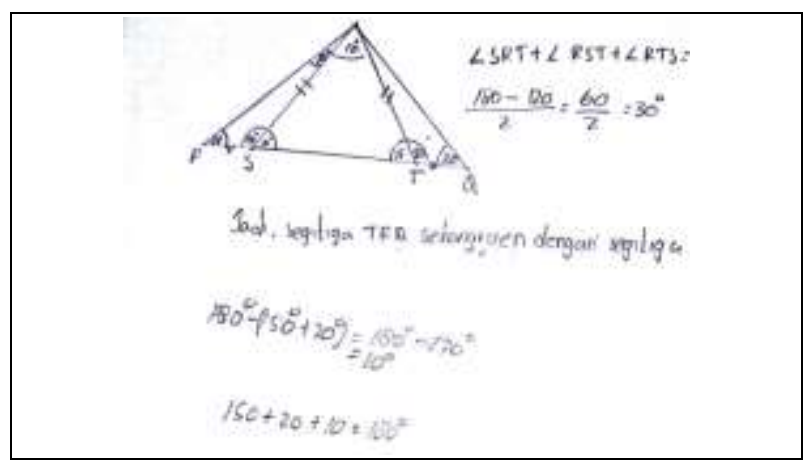

Fig. The Figure Constructed by S1

\section{B. Visualization of Subject $S 2$}

The subject does not take much time to read the problem directly take the tools to construct so that the information received and safe in the sensor memory is not enough to be continued to long-term memory then one of the consequences is that the subject cannot illustrate the geometrical object meant. The construction process is conducted by the subject with information orderly still require the hard effort by spinning the figure to recall his long-term memory concerning the visual experience. The geometrical object produced by the subject in the activity of sequential apprehension not meet the geometrical rules. The symbol used by the subject is the point name, the same length $(\mathbb{I I})_{x}$ the number represents the known angle measure. Sequential apprehension conducted by the subject is not in accordance with the geometrical rules.

The strategies used by the subject in arranging the problem-solving plan using drawing and using known information. The subject gets difficult in conducting discursive apprehension to identify the rules used explicitly. After that, the subject constructs a geometrical object one more time in the step of implementing the problem-solving plan. In the step of implementing the problem-solving plan, the subject conducts sequential apprehension again and still not similar to the geometrical rules. The subject is not able to finish the activity of discursive apprehension properly. The symbol used by the subject is the name of the point, the number represented the measure of angle, same length (II).
The last, in the step of rechecking subject use unclear rules. The following is the geometrical object constructed by the subject.

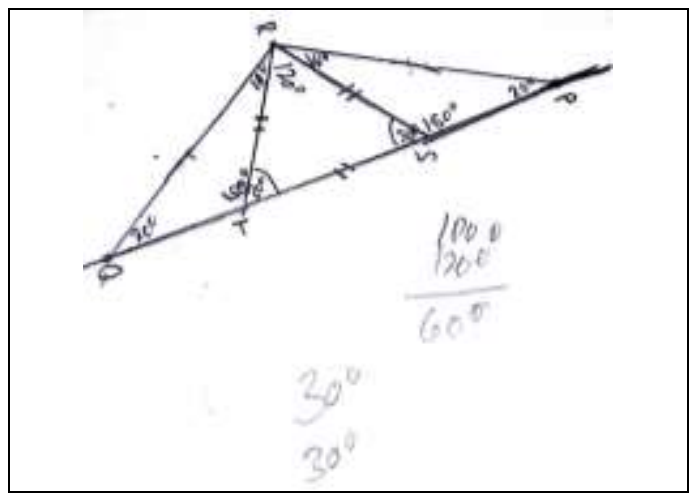

Fig. 2. The Figure Constructed by S2

The following figure 2 of $R S T$ triangle constructed by the subject not in accordance with the geometrical ruler and untidy. The symbol used is the name of the point, the number represented the measure of angle, same length (II).

\section{Comparison of Visualization of Subject S1 and S2}

$\mathrm{S} 1$ conducted perceptual apprehension in the step of the understanding problem while S2 do sequential apprehension. In the step of the problem-solving plan arrangement, S1 do sequential and discursive while S2 conduct discursive apprehension. In vice versa, in the step of implementing the plan of problem-solving S1 conduct discursive and operative apprehension and S2 do sequential, discursive and operative apprehension. In the step of rechecking the problem-solving S1 and S2 conduct discursive apprehension.

Visualization type of perceptual apprehension is not implemented by $\mathrm{S} 2$ so that when conduct the sequential apprehension find difficulty. It is shown from the construction result of the geometrical object (figure 2) where the figure is not adjusted to the rules. Meanwhile, $\mathrm{S} 1$ conducts sequential apprehension it does not directly depend on the used tools compared to S2. As for S2 the difficulties to conduct the discursive apprehension and operative apprehension compared to $\mathrm{S} 1$.

The symbol language used by $\mathrm{S} 1$ is more than $\mathrm{S} 2$. Both subject often uses verbal language in stating discursive apprehension and operative apprehension. The strategy used by both subject is not different, that is using drawing and using known information.

Students with field independent style in solving the geometrical problem are perceptual apprehension, sequential apprehension, discursive apprehension and operative apprehension. Meanwhile, the visualization types used by the students with field dependent style are sequential apprehension, discursive apprehension, and operation apprehension. There are different visualization activities conducted by the students in solving the geometrical problem based on the cognitive style for each step of problem-solving except in the step of rechecking the problem-solving. 


\section{SUGGESTION}

1. The subject of research is in the middle level of geometrical ability. It is expected that will increase the number of the subject by representing every level of geometrical ability.

2. Considering other factors that affected the visualization such as gender.

3. Students are in the learning process while skill trained to construct the geometrical object.

\section{CONCLUSION}

Visualization types used by the students with field independent style in solving the geometrical problem are perceptual apprehension, sequential apprehension, discursive apprehension and operative apprehension. Meanwhile, the visualization types used by the students with field dependent style are sequential apprehension, discursive apprehension, and operation apprehension. There are different visualization activities conducted by the students in solving the geometrical problem based on the cognitive style for each step of problem-solving except in the step of rechecking the problem-solving.

\section{ACKNOWLEDGMENT}

Acknowledgment to the headmaster and mathematics' teacher of SMPN 14 Banjarmasin.

\section{REFERENCES}

[1] L. Ahmadzade and M. Shojae, "Investigating the Relationship between Cognitive Style (Field Dependence/ Independence) and Academic Achievement in Male and Female Students of Behbahan Islamic Azad University". JLSB. 2013. 3(3),pp. 245-249.

[2] C. Alsina and R.B. Nelsen. Math Made Visual Creating Images for Understanding Mathematics. (Mathematical Association of America: New York. 2006, pp. 119-125.

[3] A, Altun and M, Cakan. "Undergraduate Students' Academic Achievement, Field Dependent/Independent Cognitive Styles and Attitude toward Computers". Journal of Educational Technology and Society. 2006.9 (1), pp. 289-297.

[4] M.Z. Aydoğdu and C, Keşan. "A Research On Geometry Problem Solving Strategies Used By Elementary Mathematics Teacher Candidates". Journal Of Educational And Instructional Studies In The World. 2014. 4(1), pp. 5362.

[5] R, Duval."Exploiting Mental Imagery With Computers In Mathematics Education," in Geometrical Picture: Kinds of Representation and Specific Processings, edited by R. Sutherland \& J. Mason (Springer: Berlin, 1995), pp. 142-153.

[6] R. Duval. "Geometry from a Cognitive Point of View" in Perspectives on the Teaching of Geometry for the 21st Century, edited by C Mammana and V Villani (Dordrecht: Kluwer, 1998), pp. 37-51.

[7] R. Duval. Representation, Vision, and Visualization: Cognitive Functions in Mathematical Thinking. Basic Issues for Learning. Proceedings of the Annual Meeting of the North American Chapter of the International Group for the Psychology of Mathematics Education. Morelos in Mexico. 1999.
[8] N. Fajriah and A. A. Suseno. "Kemampuan Siswa Sekolah Menengah Pertama dalam Menyelesaikan Masalah Matematika Berdasarkan Gaya Kognitif'. EDU-MAT Jurnal Pendidikan Matematika. 2014. 2(1), pp. 15-21.

[9] N. Fajriah and R. Amelia. Students' Mathematical Thinking Ability in Solving Geometry Problem Based on Cognitive Style. Article 5th SEA-DR. 2017. Banjarmasin Indonesia.

[10] N. Fajriah. "Rancangan Masalah Matematika Untuk Mengidentifikasi Berpikir Geometris Siswa". KALAMATIKA Jurnal Pendidikan Matematika, 2018. 3(1), pp.39-50.

[11] B. C. Gunhan. "A Case Study On The Investigation Of Reasoning Skills In Geometry". South African Journal of Education. 2014. 34(2), pp. 1-16.

[12] M. Guzman. The role of visualization in the teaching and learning of mathematical analysis. Proceedings of the 2 nd International Conference on the Teaching of Mathematics. Greece. 2002.

[13] Z, Ismail and N.L, Ali. "Pengaruh Gaya Kognitif dan Kreativitas Terhadap Penyelesaian Masalah Geometri di Kalangan Pelajar Tingkatan 4 Aliran Sains". Journal of Science and Mathematics Educational. 2011.3, pp. 46-66.

[14] K, Jones. "Issue In The Teaching and Learning of Geometry," in Aspect of Teaching Secondary Mathematics: Perspective on Practice, edited by Linda Haggarty (RoutledgeFalmer: London, 2002), pp. 121-139.

[15] S, Nasution. Berbagai Pendekatan dalam Proses Belajar \& Mengajar (Bumi Aksara: Jakarta, 2010).

[16] A, Özerem. "Misconceptions In Geometry and Suggested Solutions for Seventh Grade Students". International Journal of New Trends in Arts, Sports \& Science Education, 2012. 1(4), pp. 23-35.

[17] T. A, Pachemska, V, Gunova, L.K. Lazarova, and S, Pachemska. "Visualization of the Geometry Problems in Primary Math Education (Needs and Challenges)". Istraživanje Matematičkog. 2016.VIII(15), pp. 33-37.

[18] G, Polya, How to Solve it (New of Mathematical Method). Second Edition. (Princeton University Press: New Jersey, 1973). pp.6-9.

[19] Slameto. Belajar dan Faktor-faktor yang Mempengaruhinya. (Rineka Cipta: Jakarta, 2010).

[20] R. J, Sternberg and W.M. Williams. Educational Psychology. (Allyn-Bacon: Boston, 2002).

[21] R. A, Sukmawati and N, Fajriah, N. Kemampuan Siswa Pendidikan Dasar di Banjarmasin dalam Memecahkan Masalah Matematika ditinjau Berdasarkan Gaya Kognitif dan Gender Fakultas Keguruan dan Ilmu Pendidikan. Universitas Lambung Mangkurat. 2013.Penelitian.

[22] G, Torregrosa and H, Quesada. "The Coordination of Cognitive Processes In Solving Geometric Problems Requiring Formal Proof". Proceedings of the Joint Meeting of the32nd Conference of the International Group for the Psychology of Mathematics Education, and the XX North American. 2008. Vol. 4. pp. 321-328.

[23] A, JohnVan De Walle. Matematika Sekolah Dasar dan Menengah (Erlangga: Jakarta, 1992).

[24] S, Yin. Seeing The Value of Visualization. National Institute of Education, Nanyang Technological University, Singapore. 2010. Doctor of Education.

[25] W, Zimmermann and S, Cunningham, "Visualization in Teaching and Learning Mathematics," in The College Mathematics Journal, edited by J.J. Kaput (Traylor \& Francis Group: Washington, 1992), pp.258-260. 